UDC 378.016:811.111

DOI https://doi.org/10.32840/1992-5786.2020.70-4.23

\author{
N. M. Stetsenko \\ Candidate of Pedagogic Sciences, \\ Associate Professor of the Department of Foreign Languages \\ of Kherson National Technical University
}

I. O. Yakushenko

Senior Teacher of the Department of Foreign Languages of Kherson National Technical University

\title{
THE USE OF LMS MOODLE IN THE MODEL OF BLENDED LEARNING OF A FOREIGN LANGUAGE AT THE TECHNICAL UNIVERSITY
}

The decrease of classroom academic hours and the increase of the amount of learning material, proposed to study independently, require new approaches to learning a foreign language at higher education institutions. It is possible to solve this problem in case of wide use of information technologies which are effectively realized through $e-$ learning. In the article it is proved that - learning is an important component of professional training of experts. Besides, $e$ - learning is an integral part of distance learning, its improved form, which is constantly developing.

One of the most effective models of modern higher education is the model of blended learning, which combines traditional full -time form with elements of distance learning with the use of modern information and communication technologies. The mixed model of learning gives students more opportunity for learning a discipline so as at any time there is a possibility to look through the learning material online, do tests, check your knowledge on a separate topic or a discipline in general, study additional information.

The most effective tools for the implementation of distance learning elements in the educational process are modern electronic systems of learning management. The experience of the use of blended learning of a foreign language by means of LMS Moodle at Kherson national technical university is presented. Main peculiarities of the system Moodle within approbation of electronic educational discipline "Foreign language for specific purpose" are defined. Key characteristics of the system and main conditions for the organization of the educational process are considered. The interactive tools of the visual and educational platform Moodle which ensure the formation of intercultural professional communicative competence of specialists in future are characterized. It is described how a foreign language teacher introduces educational materials and tests in interactive form with the help of elements of the system Moodle and ensures an effective control and self control of learning outcomes. The conclusion as for the efficiency of the use of electronic courses in teaching a foreign language on the platform LMS Moodle along with the traditional form of teaching foreign languages at the university was made.

Key words: model of blended learning, LMS Moodle, electronic learning, foreign language teaching.

The problem statement. Social and economic transformations and demands of the postindustrial information society set new directions for the development and modernization of the system of professional education in Ukraine. Global experience shows the tendency to modification of traditional forms of the educational process of organization. Numerous factors facilitate this tendency such as: student - centered approach to learning; a wide base for informatization; implementation of information and communication technology (ICT); development of educational networks, online professional learning communities, widespread online learning, which gives public access to learning materials through the Internet. All these factors lead to global changes of the educational paradigm and adaptation of educational aims, objectives and principles.
The modern society needs flexible and adaptable experts who are able to process significant amounts of information, get and update knowledge, and constantly improve professional competence. But the existing system of the traditional education does not fully realize such demands of the society without fundamental changes in the educational system. In recent times researchers are interested in the model of blended learning which combines advantages of both traditional classroom learning and distance learning technologies, also in addition to being an effective way in solving the problem of providing for high level experts in the modern society. In our opinion, the use of the given model for realization of the process of teaching foreign language for specific purposes at the technical university is of particular relevance. Taking into account great educational potential and communicative importance, 
this discipline is one of the most demanding nowadays. The use of the model of blended learning in teaching foreign language is caused by decreasing of classroom academic hours and increasing the time given for students' independent work.

Analysis of recent research and publications. The problem of the educational process organization by introducing the model of blended learning is considered in the works of both foreign scientists (I.E. Allen, B. Barrett, J. Bersin, C.J. Bonk, C. Dziuban, R.V. Frazze, R. Garret, H. Kanuka, S. Kmnar, A. Rossett, R. Schank, M. Tammelin, P. Valiathan) and Ukrainian scientists (Ye. Butenkova, L. Desiatova, M. Yevdokymova, Yu. Kapustina, O. Lvova, M. Tatarynova and others). The use of the model of blended learning in foreign language teaching is presented in scientific works of V. Barkasi, S. Barkasi, M. Bondareva, T. Harbuzova, V. Kukharenko, O. Mezentseva, N. Tymoshchuk, O. Shcherbakova and others.

In spite of a large number of researches of blended learning implementation in the educational process of higher education institutions, there are a number of problems which need to be solved.

The aim of the article is to examine possibilities of the use of Learning Management System (LMS) Moodle in the model of blended learning in teaching foreign language at the technical university.

Presentation of basic material of the research. Blended learning is a model which mixes elements of full - time and distance learning. The students' learning outcomes will be high in case of using this method methodologically correct. The model of blended learning is not simply the use of ICT in students' independent work, but it is the integral educational process which implies training students partly under the teacher's guidance and partly through distance learning in individual or group kinds of independent work.

Blended learning combines elements of the main European educational models:

1) Distance learning;

2) Face to face learning;

3) Online learning.

There are six models for blended learning in foreign practice:

1. Face - to - Face Driver Model. Technology is used alongside traditional teaching. This is a good option for classrooms where students are performing at various levels of skill and ability. Most of the class is led by face-to-face lessons. The introduction of online instruction is decided on a case-by-case basis.

2. Rotation Model. There is a fixed schedule by which students have face-to-face time with their teachers and then move to online work.

3. Flex Model. A great part of the material is delivered online. Although teachers are in the room to provide on-site support as needed, learning is primarily self-guided, as students independently learn and practise new concepts in a digital environment.

4. Online Lab Model. Students learn entirely online but travel to a dedicated computer lab to complete their coursework. Adults supervise the lab, but they are not trained teachers.

5. Selfblend Model. The model is traditional for higher education institutions in the USA. It gives students the opportunity to take classes beyond what is already offered at their school. While these individuals will attend a traditional school environment, they also opt to supplement their learning through online courses offered remotely.

6. Online Driver Model. Students work remotely and material is primarily delivered via an online platform. Although face-to-face check-ins are optional, students can usually chat with teachers online if they have questions [7].

Rotation Model is the most effective model of foreign language teaching because foreign language mastery needs "live" communication. Accordingly, teaching is based not only on the interaction between students and a computer, but with a teacher in an active way as well. The material learnt independently is summarized and used in real conditions through discussion of communicative tasks. [3, p. 45].

Consequently, the model of blended learning can be characterized by three main components:

1. The component of traditional direct interaction of participants of the educational process.

2. The component of interactive communication through computer technologies and electronic information and education resources.

3. The component of self - study.

$\mathrm{E}$ - learning, as an element of blended learning in a modern higher education institution, is the use of Learning Management System (LMS), which is a set of software and hardware elements based on the Internet technology, methodology of teaching and organizational arrangements. Main functions of LMS is registration of participants, delivery of educational content, supporting of different kinds of interaction between students and teachers, control of learning outcomes, collection of statistical information of academic work, regeneration of reports and etc. $[5,105]$.

Nowadays, there are many different systems of e - learning such as BlackBoard, WebCT, TopClass, ILIAS, MOODLE and etc.

Modular Object-Oriented Dynamic Learning Environment is the most popular electronic platform used at Ukrainian higher education institutions. Moodle is a free (licensed under GNU GPL) web application, which gives opportunity to create sites for online learning. The system is designed, first of all, to organize interaction between a teacher and students, and also it is suited to organize traditional distance 
learning courses and support full - time form of education [4, p. 808].

The learning environment gives teachers tools to create online courses and only subscribed students have an access to them. Teachers and students have opportunities to add material to the online course, have online discussions, take part in charts, do tests, question, send and correct tasks.

The educational Moodle platform gives teachers and students opportunities for unlimited access to different educational resources. On the platform one can put reference materials required for independent work, tests with automatic correction, and it can help a teacher reduce work time, and a student can get immediately results of his or her work and analyze mistakes.

The use of the Moodle platform encourages individualization of learning. Materials and tasks are various enough and respond to individual characteristics of students as much as possible.

As a result, we believe that the use of the Moodle platform in the model of blended learning is quite effective method of organization of foreign language teaching of students in the technical university.

Since 2016 the model of blending learning is implemented in Kherson national technical university. This is the priority of the university. The complex training program and the use of electronic educational resources are being carried out effectively during recent years in KNTU. The program includes a set of arrangements aimed at providing students of all forms of education with modern electronic educational resources, their dynamic modernization and actuality.

In KNTU specialized structures for creation and administration of the environment for management of electronic educational resources and their development and implementation in the educational process are formed. All the developed electronic educational resources are available in a university LMS for organization of the centralized management of the educational process. Therefore, every university student uses electronic educational resources in their learning.

The teachers of the department of foreign languages of the university teach the discipline "Foreign language for specific purpose" and work hard with the method of blended learning, using resources of the Moodle platform.

Rotation Model was chosen to organize learning, which means combining classroom and independent work of the students.

Independent work in the discipline of foreign language includes:

1. Doing lexical and grammar drills which usually take much time at the lesson. Control of done exercises can be realized through e - learning.

2. Doing written tests which include different forms of control.
3. Doing tasks aimed at the formation and development of listening skills and reading of different texts with different aims.

4. Writing various kinds of compositions and essays.

5. Reference papers, project works, with the further presentation at lessons [2, p. 44].

Independent work is organized in the e-course environment which is put on the Moodle platform. All the tasks are done by students independently at home. The course is aimed at development of reading and writing skills, expanding glossary and it includes four main modules with different tasks. Each module is completed with a final test.

The content of the module includes standard learning resources (a book, a hyperlink, a folder, a file, a web - page etc.) and activity - related components which need students' active part (tasks, a glossary, a forum, a chat, a seminar etc.) that makes it possible to diversify learning material, methods for control and self - control of students' knowledge and ensure interaction between a teacher and all the users of the course [6, p. 419].

In our opinion, the most effective learning elements of the discipline "Foreign language for specific purpose" are a glossary, a database, tasks, a book, a test, and a forum.

The Glossary element allows organizing work with terms; it is used for completing a glossary of every separate Units and Modules. Both teacher and students can complete a glossary. Students alone can add words and expressions on the topic to the glossary. A teacher can edit students' records and assess assignments.

The Database element allows a teacher or students to create structured records on the previous topic. Besides records there can be some pictures, texts, lists etc. Working with the Database element motivates students to search for new information on the topic. Also, a teacher can edit students' records and assess assignments.

The Task element allows a teacher to set an objective and students need to prepare a detailed answer, a presentation, and a report or do some types of exercises. A teacher can assess assignments and leave a comment.

The Book resource is useful to put information in the form of a text or tables in the discipline "Foreign language". This resource can be combined with the Lecture resource that makes it possible to present information in a clear format. In this case, a teacher can ask students and they have to answer them. If a student answer questions correctly, he or she can go to the next section. If a student does wrong, Moodle sends him or her back to revise learning material. The best way to study grammar is to use these resources.

The Test element allows a teacher to make up a set of test questions of different types. Moodle has standard types of questions which could be 
used in the discipline of "Foreign language for specific purpose". Such questions are the following: 1) Multiple Choice with one or some choices; 2) True - false; 3) Tell the Difference with the choice of an answer to every given question from the list of available questions; 4) Select the Missing Words; 5) Short Answer; 6) Drag and Drop in the Text where missing words in the text are moved with the cursor; 7) Drag and Drop onto Image means dragging a picture or a text with the help of the cursor to the area of the background image; 8) Essay in which one can have an answer containing a few sentences or paragraphs.

All the types of types can be almost assessed automatically with Moodle. Essay is evaluated manually by a teacher.

Furthermore, resources of the Moodle system allow a teacher of a foreign language to make puzzles and assess students, who solve them. Puzzles are an interesting interactive form of work in learning of different aspects of a foreign language.

The Forum element can be used to discuss educational problems and consult online.

So, the use of resources of LMS Moodle allows teachers of a foreign language to provide the course with modern, interesting learning material, and students are engaged in interactive methods of learning of a foreign language.

Conclusions. The use of LMS Moodle in the method of blended learning of a foreign language teaching favors optimization of the educational process in conditions of the shortage of classroom academic hours. Thus, the students have an opportunity to control the educational process and it motivates their significant realization of educational aims and influences their motivation.

In our opinion, choice of balance between the forms of classroom and distance learning and the methodology for the development and improvement of distance learning courses of a foreign language are the issues of further research.

\section{References:}

1. Баркасі В., Баркасі С. Використання змішаної форми навчання при викладанні іноземних мов у ВНЗ. Молодий вчений. 2015. № 2(17). C. 203-206.

2. Бондарев М.Г. Модель смешанного обучения иностранному языку для специальных целей в електронной образовательной среде технического вуза. Известия ЮФУ. Технические науки. 2012. № 10(135). C. 41-48.

3. Бондарева Е.В. Профессиональная компетентность специалиста в условиях становления информационного общества. Вестник Волгоградского государственного универсиmema. 2003, № 6. C. 44-48.

4. Корень А.В., Ивашинникова Е.А., Голояд А.Н. Использование современных информационно-коммуникационных технологий в учебном процессе. Международный журнал прикладных и ффундаментальных исследований. 2016. № 8-5. С. 806-808.

5. Соловов А.В. Электронное обучение: проблематика, дидактика, технология. Самара : Новая техника, 2006. 462 с.

6. Худолей Н.В. Использование LMS Moodle при обучении иностранного языка в вузе (из опыта ФГБОУ ВО «Красноярский ГАУ»). Вестник РУДН. Серия Информатизация образования. 2018. № 15(4). C. 410-423.

7. Bonk C.J., Graham C.R. Handbook of blended learning : Global perspective, local designs. - San Francisco, C.A. : Pfeiffer Publishing, 2006. 571 p.

8. Valiathan P. Blended Learning Models, 2002. URL: https://www.purnima-valiathan.com/wp-content/ uploads/2015/09/Blended-Learning-Models-2002ASTD.pdf.

Стеценко Н. М., Якушенко I. О. Використання LMS Moodle у моделі змішаного навчання іноземної мови в технічному університеті

Зменшення аудиторних годин і збільшення обсягу навчального матеріалу, що виноситься на самостійне опанування, потребує нових підходів до вивчення іноземної мови в закладах вищої освіти. Розв'язати це питання можливо за умови широкого використання інформаційних технологій, що найбільш ефрективно реалізуються через електронне навчання. У статті доведено, що електронне навчання є необхідним компонентом професійної підготовки фрахівців. Крім того, електронне навчання $\epsilon$ складовою частиною дистанційної освіти, ї̈ покращеною формою, що постійно розвивається.

Однією з найбільш ефективних моделей сучасної вищої освіти є модель змішаного навчання, що поєднує традиційну очну форму з елементами дистанційного навчання з використанням сучасних інфрормаційно-комунікаційних технологій. Змішана модель навчання надає студентам більше можливостей для вивчення дисципліни, оскільки в будь який час є можливість переглянути навчальний матеріал онлайн, пройти тестування, перевірити свої знання з окремої теми чи дисципліни в цілому, ознайомитися з додатковими джерелами інформації.

Найбільш ефрективними інструментами впровадження дистанційних елементів у навчальний процес є сучасні електронні системи управління навчанням. У роботі представлено досвід реалізації змішаного навчання іноземної мови у Херсонському національному технічному університеті 
засобами LMS Moodle. Визначено основні особливості системи Moodle в межах апробації електронного освітнього курсу «Іноземна мова за професійним спрямуванням». Наведено ключові характеристики системи, основні умови організації навчального процесу. Охарактеризовано інтерактивний інструментарій віртуальної освітньої платформи Moodle, що забезпечує фрормування міжкультурної профресійної комунікативної компетенції у майбутніх фрахівців. Описано, як за допомогою навчальних елементів системи Moodle викладач іноземної мови може розмістити навчальні матеріали та засоби контролю в ефективній інтерактивній формі, забезпечити ефрективний контроль і самоконтроль засвоєння навчального матеріалу. Зроблено висновок про доцільність використання в навчальному процесі університету електронних курсів з іноземної мови на платформі LMS Moodle в комплексі із традиційною формою організації навчання.

Ключові слова: модель змішаного навчання, LMS Moodle, електронне навчання, навчання іноземної мови. 